\title{
Heavy Metals in Garra gotyla, Cyprinus carpio and Cyprinion watsoni from the River Panjkora, District, Lower Dir, Khyber Pakhtunkhwa, Pakistan
}

\author{
Sana Ullah"; ${ }^{1}$ Zaqhim Hussain ${ }^{1}$; Shahid Mahboob ${ }^{2,3 *}$; Khalid Al-Ghanim² \\ ${ }^{I}$ Quaid-i-Azam University, Islamabad, Pakistan; ${ }^{2}$ Department of Zoology, College of Science, P. O. Box 2455, King \\ Saud University, riyadh, Saudi Arabia; ${ }^{3}$ Government College University Faisalabad, AFaisalabad, Pakistan.
}

\begin{abstract}
This study was conducted in the River Panjkora, Pakistan, in order to assess the level of heavy metals accumulated in the liver, kidneys, gills and muscle tissues of three highly consumed fish species by the local community, Garra gotyla, Cyprinus carpio and Cyprinion watsoni. The heavy metals including manganese (Mn), iron (Fe), chromium $(\mathrm{Cr})$, zinc $(\mathrm{Zn})$, lead $(\mathrm{Pb})$, cadmium $(\mathrm{Cd})$ and nickel $(\mathrm{Ni})$ were determined in the collected fish specimens through an atomic absorption spectrophotometer. Level of heavy metals significantly varied depending upon tissues type and fish species. Cyprinus carpio accumulated highest concentration of heavy metals, followed by Garra gotyla while Cyprinion watsoni accumulated least concentration of heavy metals. All the three species displayed significant differences in level of accumulated heavy metals. The order of accumulation in tissues was gills $<$ muscles $<$ kidney $<$ liver. $\mathrm{Cd}$ and $\mathrm{Ni}$ were not detected in all collected specimens while Mn was not detected in the tissues of Cyprinion watsoni collected from the reference site.
\end{abstract}

Key words: River; Control site; Tissues; Pollution; Heavy Metals

*Authors for correspondence: shahidmahboob60@hotmail.com 


\section{INTRODUCTION}

Different natural sources and anthropogenic activities lead to heavy metals pollution [1-2]. However, in fluvial environmental setup, it may be a result of geologic weathering, atmospheric deposition or discharge of industrial, residential, municipal and agricultural discharge [3]. Heavy metals distribution in sediments, adjacent to settlements, may provide evidence of the impacts of anthropogenic activities on ecosystems. The accumulation of heavy metals in sediments plays a predominant role, and its consequences affect local communities in general and water quality of the river specifically, which is home for a number of edible aquatic organisms. Many invertebrate organisms use sediments as their food source and may accumulate toxic metals, a threat to many healthy species at the top of the food chain, specifically fish, birds and human beings [4]. Moreover, the repossession of the metals from contaminated sediments of the rivers or streams poses a substantial risk to local masses via fish consumption or through the remobilization of metals into crops from agricultural lands [5]. The presence of these metals in higher amount or in over permissible limits threatens the health of aquatic animals as well as terrestrial ones including men [6]. Certain heavy metals such as iron, zinc and copper are necessary for metabolism in fish, whereas others, such as lead, cadmium and mercury play no identified role in the fish biological system [7]. For maintaining normal metabolism, essential metals must be present in optimum concentrations and taken up from sediments, food and ambient water. However, like the essential ones, the nonessential metals are also taken up and accumulated in different tissues of the fish. Previous studies conducted in both laboratory environments as well as in the fields revealed heavy metal accumulation in various concentrations in different fish tissues, primarily dependent upon exposure period and the concentrations of the heavy metals in the ambient water, though other environmental factors including temperature, hardness, $\mathrm{pH}$ and salinity also play a key role [8]. Accumulation of the heavy metals in fish is also dependent upon size, sex, life cycle, feeding behaviour, capture season and ecological needs of the fish [1-2].
Fish is considered as the best sentries for the investigation of an environmental health and the pollution status of the aquatic ecosystems [9]. Heavy metals accumulate in the food chain, and adversely affect fish. Consequently, it sometimes leads to mass mortality [10] or alters the physiology and biochemical aspects of the fish [11]. On account of its economic worth and public health value, research regarding heavy metal contents in fish tissues has been carried out in different parts of the world as well as Pakistan [12-15]. Studies conducted on river Kabul revealed the presence of heavy metals in different fish species including Tor putitora, Ompok bimaculatus, Aorichthys seenghala, Cyprinus carpio, Labeo dyocheilus and Wallago attu in a higher concentration than the permissible limits [16-18]. Many recent studies reports the presence of heavy metals in various fish species from different parts of the country [19-21]. Keeping in view the current scenario of an increase in heavy metal concentrations in different freshwater bodies in Pakistan, and the increasing risks associated with consumption of fish having higher concentrations of toxic metals, the current study was carried out to determine concentrations of different heavy metals in the kidneys, liver, gills and muscle tissues of three highly consumed fish species (Garra gotyla, Cyprinus carpio and Cyprinion watsoni) from the river Panjkora, Pakistan.

\section{MATERIALS AND METHODS}

2.1 Study Area: District Lower Dir is situated at $71^{\circ}$, $31^{\prime}$ to $72^{\circ}, 14^{\prime}$ east and $34^{\circ}, 37^{\prime}$ to $35^{\circ}, 07^{\prime}$ north, respectively in the Hindukush range (Ullah and Ahmad, 2015) and is about 2700 feet above sea level. It is bounded to west by Bajaur Agency (FATA) and Afghanistan, to east by Swat district, to south by Malakand district and to north by the Chitral district [22]. River Panjkora originates from Kohistan Upper Dir district and flows through the Lower Dir District, dividing the districts into two halves, and later on joins river Swat at Sharbati, Bosaq pull, behind District Malakand. River Panjkora is composed of five main streams in Upper Dir district, while two streams in Lower Dir district [Fig. 1]. 


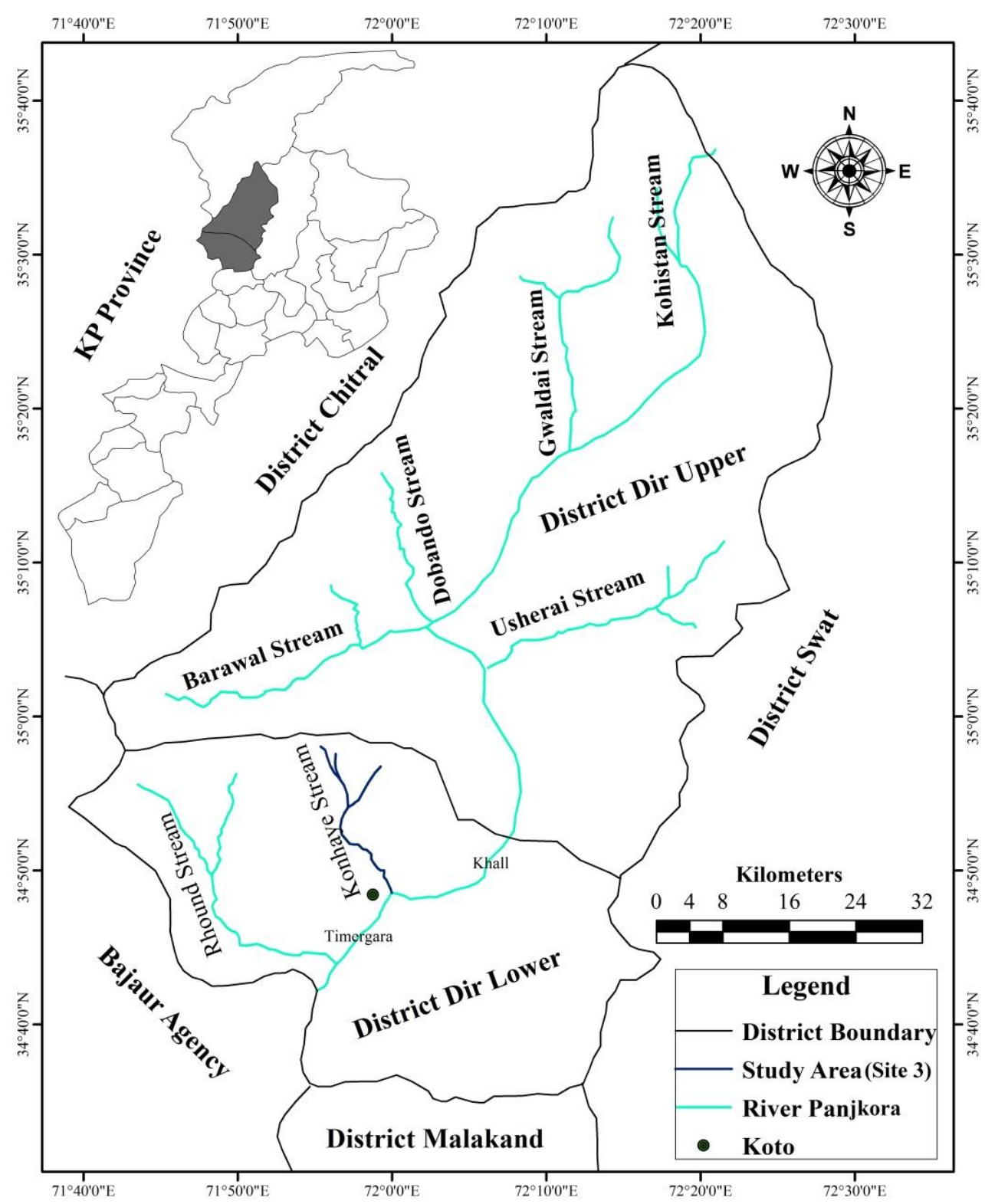

Figure 1: Sampling sites within the study area in river Panjkora at Lower Dir district

2.2 Sampling and analysis: Nine specimens of each species, from two distinct and highly populated areas (Khall: Upstream and Timergara: Downstream) of the district, and a pollution free as control site (Konhaye stream: a tributary joining the Panjkora river at Koto) were collected. The fish were shifted to the research laboratory after washing with tap water and dissected plastic knife. The kidney, muscles, liver and gills samples were weighed, packed properly and froze at $-20^{\circ} \mathrm{C}$ for analysis. "The tissue samples were thawed at room temperature before analysis. Approximately $1 \mathrm{~g}$ (gills, liver, kidney and muscle) was weighed in an
Erlenmeyer flask and digested with $5 \mathrm{ml}$ Perchloric acid and $15 \mathrm{ml} \mathrm{HNO3}$ on a hot plate until brown fumes ceased to evolve, then samples were cooled at room temperature, diluted with $50 \mathrm{ml}$ distilled water by following [21]".

\subsection{Analysis of fish samples}

Samples of gills, kidney, liver and muscle of Garra gotyla, Cyprinus carpio and Cyprinion watsoni in triplicates were analysed by following the methods as described by [1-2]. Heavy metals including manganese $(\mathrm{Mn})$, iron $(\mathrm{Fe})$, chromium $(\mathrm{Cr})$, zinc $(\mathrm{Zn})$, copper $(\mathrm{Cu})$, lead $(\mathrm{Pb})$, cadmium $(\mathrm{Cd})$ and nickel (Ni) were detected by using Atomic 
Absorption Spectrometer (Z-2000 Hitachi). "Sample of fish organs viz. gills, liver, kidney and muscle were digested, separately with concentrated nitric acid. $0.5 \mathrm{gm}$ of each sample was taken in a $100 \mathrm{ml}$ tube and $3 \mathrm{ml}$ of concentrated $\mathrm{HNO}_{3}$ was added. Samples were heated in tubes at 100, 150, 200 and $250^{\circ} \mathrm{C}$ on a hot plate for 1.0, 1.0, 1.0 and $1.5 \mathrm{hr}$, respectively. $2 \mathrm{ml}$ of $1 \mathrm{~N} \mathrm{HNO}_{3}$ was added to the residue and the solution was evaporated again on a hot plate, continuing until sample was completely digested and become colourless. The sample was cooled and $10 \mathrm{ml}$ of $1 \mathrm{~N} \mathrm{HNO}_{3}$ was added again. Digested sample was transferred to $500 \mathrm{ml}$ volumetric flask to make the volume by using the double distilled water. The digested sample volume was filtered through $0.45 \mu \mathrm{m}$ Millipore membrane filter. The filtrate was analysed for $\mathrm{Mn}, \mathrm{Fe}, \mathrm{Cr}, \mathrm{Zn}, \mathrm{Cu}, \mathrm{Pb}, \mathrm{Cd}$ and $\mathrm{Ni}$ according to [1-2]". The blanks and calibration standard solution were also analysed in the same way as for the samples. The instrument calibration standards were prepared by diluting standard (1000 ppm) supplied by Merck, Germany. A known 1000 $\mathrm{mg} / \mathrm{l}$ concentration of $\mathrm{Pb}, \mathrm{Cu}, \mathrm{Fe}$ and $\mathrm{Cr}$ solution was prepared from their salts. All reagents used were of analytical grade purchased from Merck, Germany.

2.4 Statistical Analysis: Data from the experiment were expressed as mean \pm standard error and were analysed through one-way analysis of variance (ANOVA) followed by LSD test using Statistix 8.1. Level of significance was considered significant statistically at $\mathrm{P}<0.05$. Map of the study area was prepared using ArcGIS V. 9.3.

\section{RESULTS}

Among the studied heavy metals, cadmium and nickel were under detectable concentrations, whereas the rest of the metals ranged in different concentrations, both location and species wise. The overall comparison revealed the level of heavy metals was higher at downstream (Timergara) followed by upstream (Khall), whereas the minimum least concentrations were observed in fish specimens collected from Konhaye stream (reference site). Among the three fish species highest concentration was recorded in $C$. carpio followed by G. gotyla and C. watsoni. The order of accumulation of heavy metal in tissues was gills $<$ muscles $<$ kidney $<$ liver.

In Garra gotyla the order of accumulation of heavy metals was detected as $\mathrm{Mn}<\mathrm{Pb}=\mathrm{Cu}<\mathrm{Cr}<\mathrm{Zn}<\mathrm{Fe}$ and $\mathrm{Mn}<\mathrm{Pb}=\mathrm{Cu}=\mathrm{Cr}<\mathrm{Zn}$ at upstream followed by downstream and reference site. $\mathrm{Ni}$ and $\mathrm{Cd}$ were not detected in any of the collected specimens from all the three sampling sites (Figure 2). Heavy metals accumulated in the kidney of $G$. gotyla in the order of $\mathrm{Mn}<\mathrm{Pb}=\mathrm{Cu}=\mathrm{Cr}<\mathrm{Fe}<\mathrm{Zn}$, $\mathrm{Mn}<\mathrm{Pb}=\mathrm{Cu}=\mathrm{Cr}<\mathrm{Zn}<\mathrm{Fe}$ and $\mathrm{Pb}=\mathrm{Cu}=\mathrm{Cr}<\mathrm{Fe}<\mathrm{Zn}$ at upstream, downstream and reference site, respectively. Mn was not detected in the of $G$. gotyla collected from control site (Figure 3 ). The order of accumulation of heavy metals in gills was $\mathrm{Mn}<\mathrm{Pb}=\mathrm{Cr}=\mathrm{Cu}<\mathrm{Zn}<\mathrm{Fe}, \quad \mathrm{Mn}<\mathrm{Cu}=\mathrm{Cr}<\mathrm{Pb}<\mathrm{Fe}<\mathrm{Zn}$ and $\mathrm{Cu}=\mathrm{Cr}<\mathrm{Fe}=\mathrm{Zn}$ at upstream, downstream and reference site, respectively. However, $\mathrm{Pb}$ and $\mathrm{Mn}$ was not detected in the gills of control fish (Figure $4)$. The order of accumulation in muscle tissues was $\mathrm{Mn}=\mathrm{Pb}<\mathrm{Cr}=\mathrm{Cu}<\mathrm{Zn}=\mathrm{Fe}, \quad \mathrm{Mn}=\mathrm{Pb}<\mathrm{Cu}=\mathrm{Cr}<\mathrm{Zn}<\mathrm{Fe}$, and $\mathrm{Cu}=\mathrm{Cr}<\mathrm{Zn}<\mathrm{Fe}$ at upstream, downstream and reference site, respectively. $\mathrm{Mn}$ and $\mathrm{Pb}$ were not detected in muscle samples of $G$. gotyla from reference site (Figure 5). 


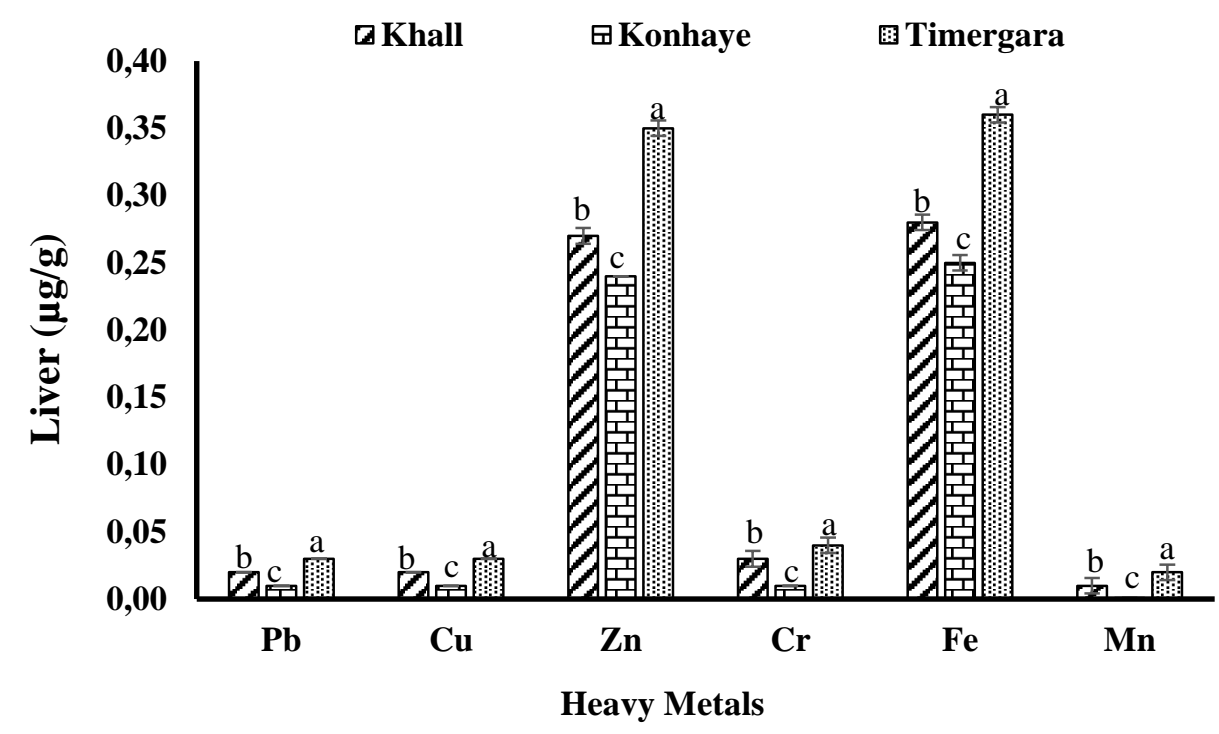

Figure 2: Concentration $(\mu \mathrm{g} / \mathrm{g})$ of heavy metals in G. gotyla liver

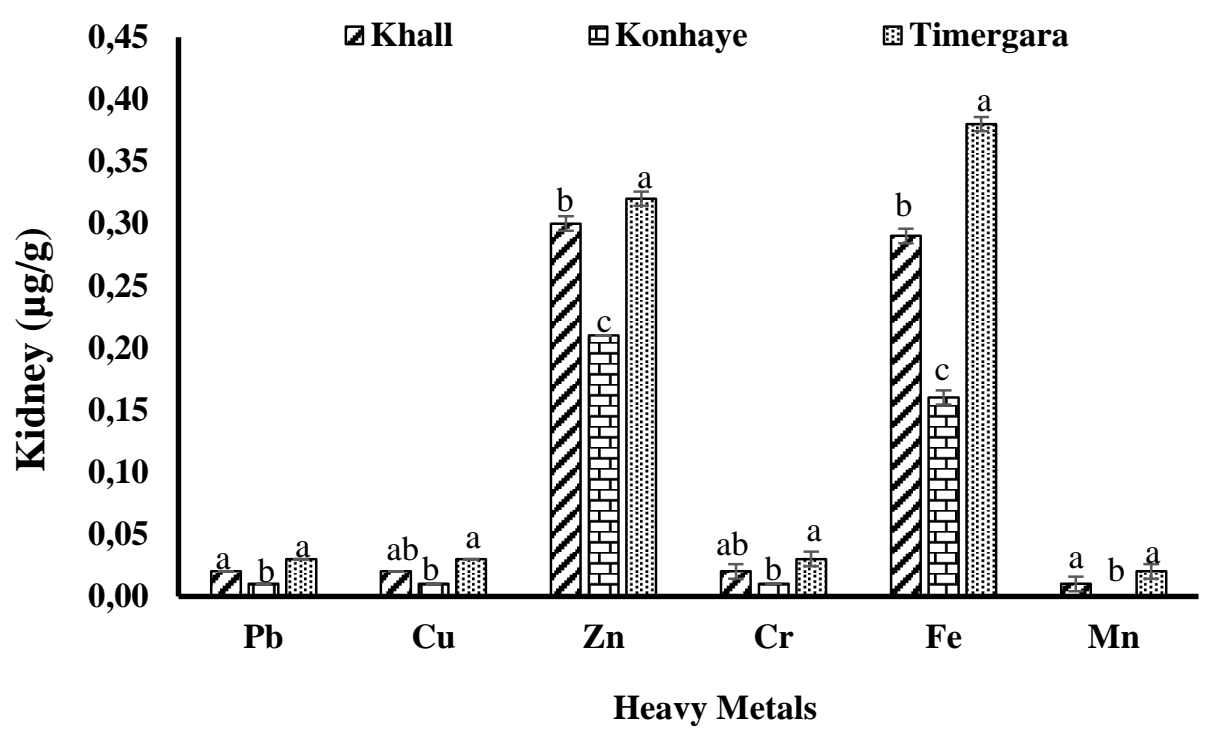

Figure 3: Concentration $(\mu \mathrm{g} / \mathrm{g})$ of heavy metals in G. gotyla kidney 


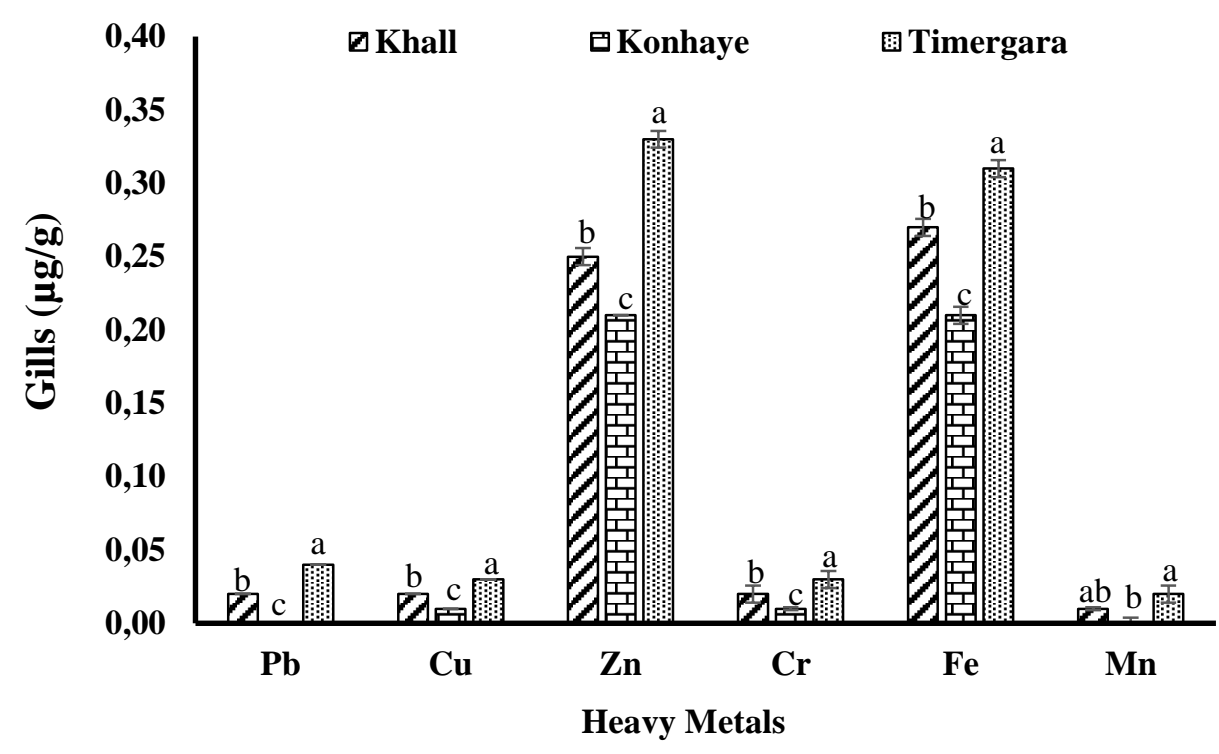

Figure 4: Concentration $(\mu \mathrm{g} / \mathrm{g})$ of heavy metals in $G$. gotyla gills

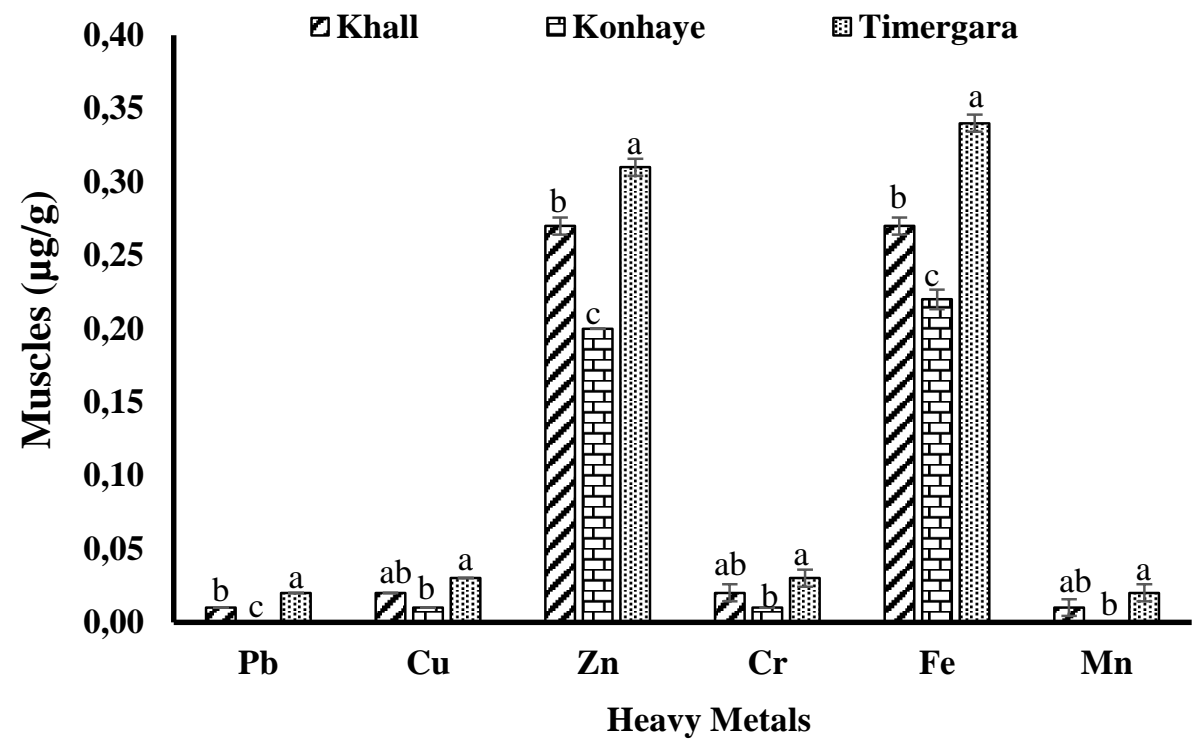

Figure 5: Concentration ( $\mu \mathrm{g} / \mathrm{g})$ of heavy metals in G. gotyla muscle

In Cyprinus carpio $\mathrm{Ni}$ and $\mathrm{Cd}$ were not detected in any tissue samples of fish collected from upstream, downstream and control site. The order of accumulation of heavy metal in liver of $C$. carpio was

$\mathrm{Mn}=\mathrm{Cu}<\mathrm{Cr}=\mathrm{Pb}<\mathrm{Zn}<\mathrm{Fe}$ $\mathrm{Mn}=\mathrm{Pb}=\mathrm{Cu}<\mathrm{Cr}<\mathrm{Fe}<\mathrm{Zn}$, $\mathrm{Mn}<\mathrm{Pb}=\mathrm{Cu}=\mathrm{Cr}<\mathrm{Fe}<\mathrm{Zn}$ at upstream, downstream and reference site, respectively (Figure 6). The order of accumulation of heavy metals in the kidney was $\mathrm{Mn}=\mathrm{Cu}=\mathrm{Cr}<\mathrm{Pb}<\mathrm{Fe}<\mathrm{Zn}$, $\mathrm{Mn}=\mathrm{Cr}<\mathrm{Pb}=\mathrm{Cu}<\mathrm{Fe}<\mathrm{Zn}$ at upstream, downstream and reference site, respectively (Figure 7). In gills the order of accumulation of these metals was $\mathrm{Mn}<\mathrm{Cr}=\mathrm{Pb}=\mathrm{Cu}<\mathrm{Fe}<\mathrm{Zn}, \quad \mathrm{Mn}<\mathrm{Pb}=\mathrm{Cu}<\mathrm{Cr}<\mathrm{Fe}<\mathrm{Zn}$ and $\mathrm{Pb}=\mathrm{Cr}=\mathrm{Cu}<\mathrm{Fe}<\mathrm{Zn}$ at upstream, downstream and reference site, respectively (Figure 8). The order of heavy metals in muscle tissues of $C$. carpio was $\mathrm{Mn}<\mathrm{Cr}=\mathrm{Cu}=\mathrm{Pb}<\mathrm{Zn}<\mathrm{Fe}$, $\mathrm{Mn}=\mathrm{Cu}=\mathrm{Pb}<\mathrm{Cr}<\mathrm{Zn}>\mathrm{Fe}$ and $\mathrm{Pb}=\mathrm{Cu}=\mathrm{Cr}<\mathrm{Fe}<\mathrm{Zn}$ at upstream, downstream and reference site, respectively (Figure 9). 


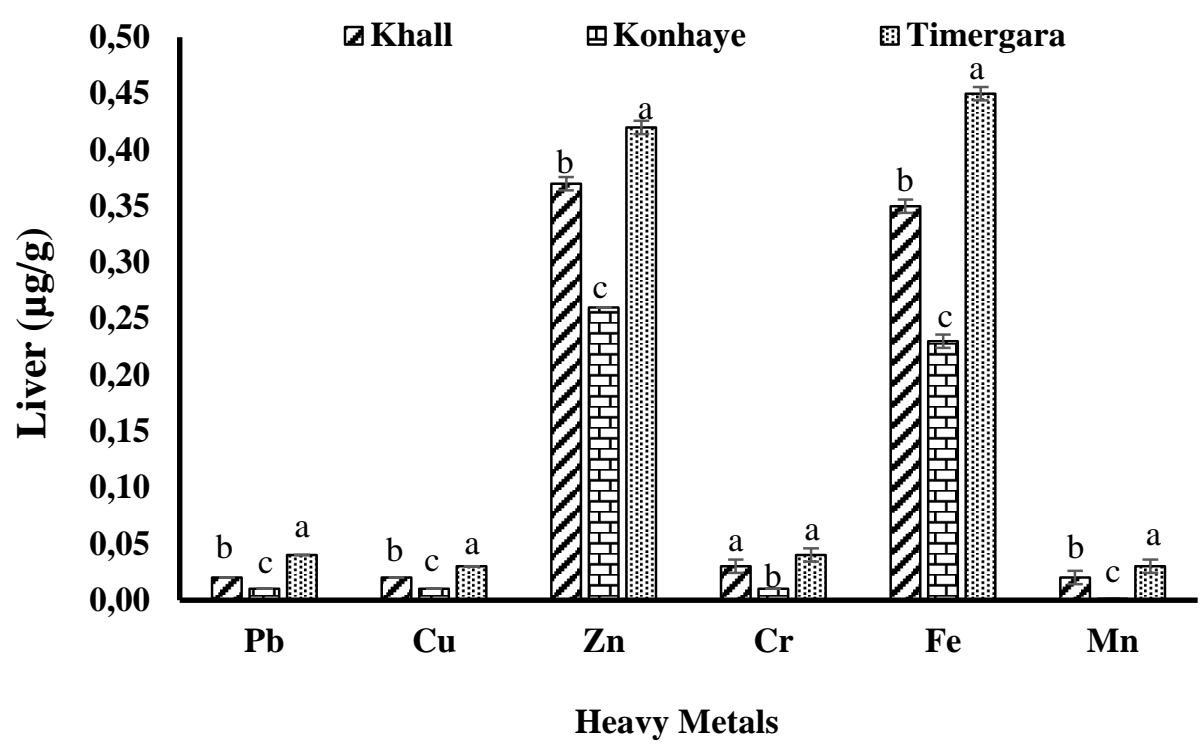

Figure 6: Concentration $(\mu \mathrm{g} / \mathrm{g})$ of heavy metals in C. carpio liver

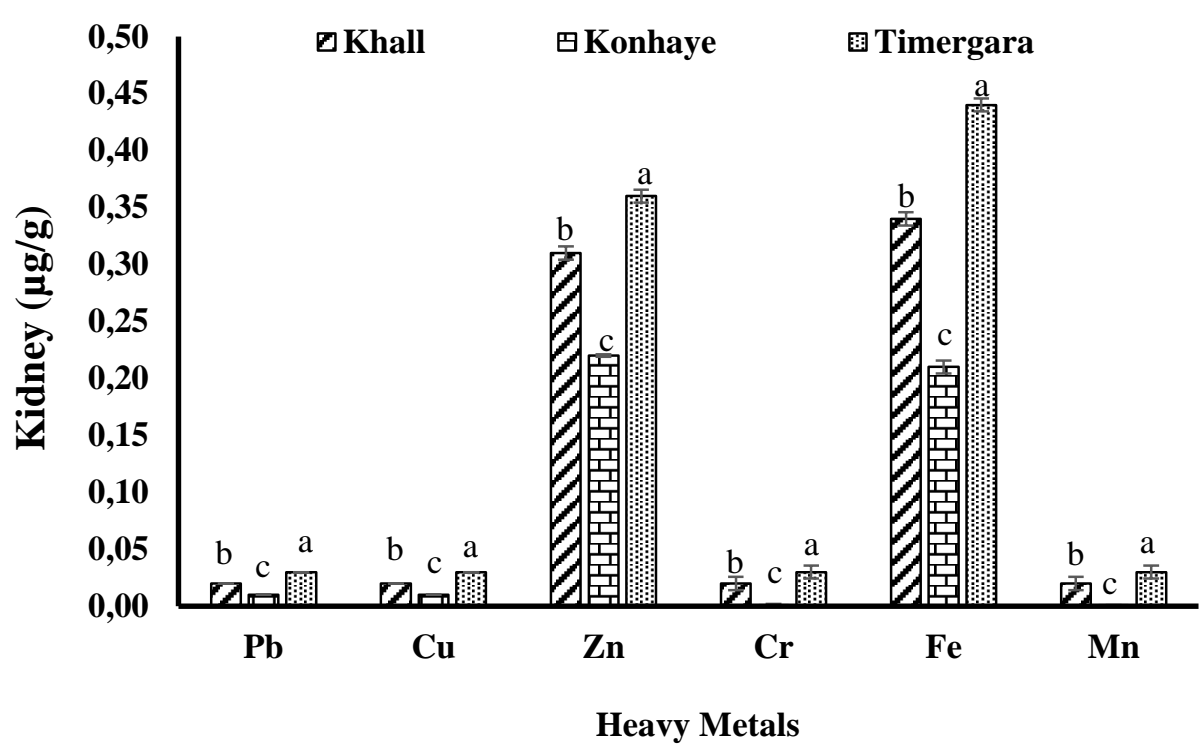

Figure 7: Concentration $(\mu \mathrm{g} / \mathrm{g})$ of heavy metals in $C$. carpio kidney 


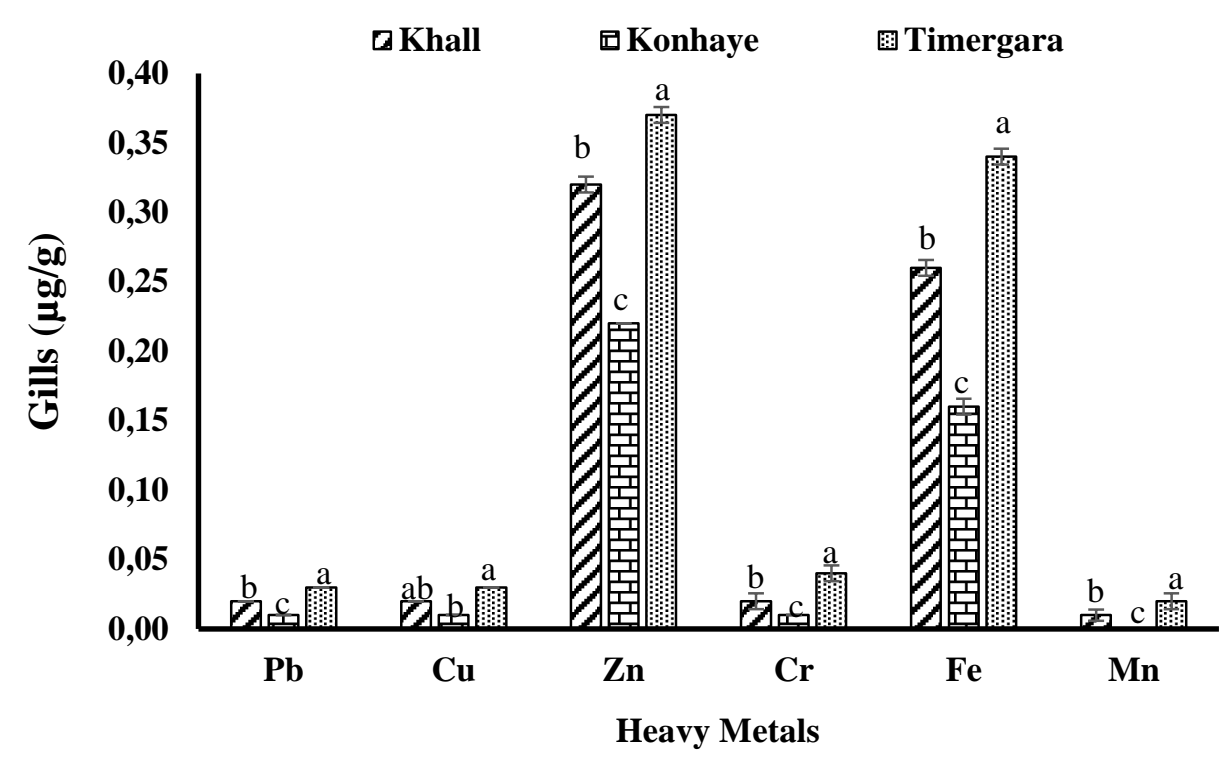

Figure 8: Concentration $(\mu \mathrm{g} / \mathrm{g})$ of heavy metals in C. carpio gills

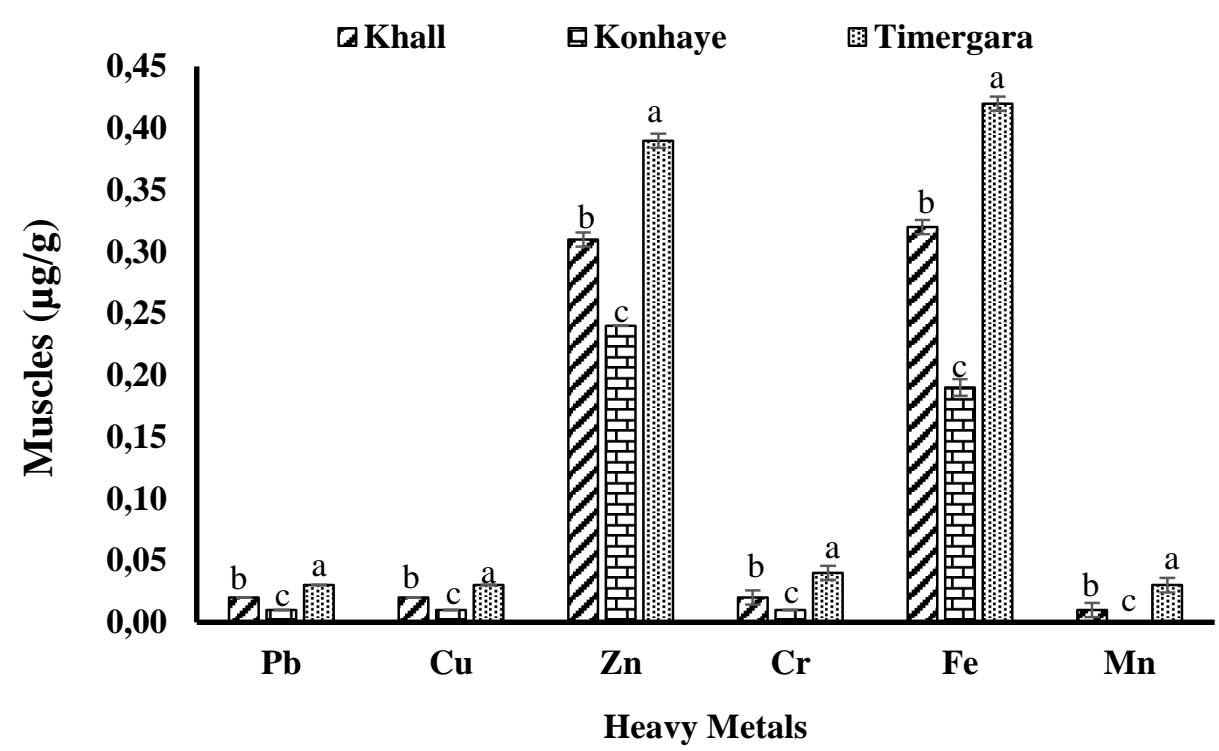

Figure 9: Concentration $(\mu \mathrm{g} / \mathrm{g})$ of heavy metals in $C$. carpio muscles

Mn was not detected in the samples of Cyprinion watsoni procured from control site. The order of accumulation of heavy metals in the liver of $C$. watsoni was as $\mathrm{Mn}<\mathrm{Pb}=\mathrm{Cu}=\mathrm{Cr}<\mathrm{Zn}<\mathrm{Fe}$, $\mathrm{Mn}<\mathrm{Cu}<\mathrm{Pb}=\mathrm{Cr}<\mathrm{Zn}<\mathrm{Fe}$ and $\mathrm{Pb}=\mathrm{Cu}=\mathrm{Cr}<\mathrm{Fe}<\mathrm{Zn}$ collected from upstream, downstream and control sites, respectively (Figure 10). In kidneys the order of heavy metals was observed as $\mathrm{Mn}<\mathrm{Pb}=\mathrm{Cu}=\mathrm{Cr}<\mathrm{Fe}=\mathrm{Zn}, \quad \mathrm{Mn}<\mathrm{Pb}=\mathrm{Cu}=\mathrm{Cr}<\mathrm{Zn}<\mathrm{Fe}$ and $\mathrm{Pb}=\mathrm{Cr}=\mathrm{Cu}<\mathrm{Zn}<\mathrm{Fe}$ in fish collected from upstream, downstream and reference site, respectively (Figure 11). The order of accumulation of heavy metals in gills was as $\mathrm{Mn}=\mathrm{Cr}<\mathrm{Cu}<\mathrm{Pb}<\mathrm{Zn}<\mathrm{Fe}, \quad \mathrm{Mn}<\mathrm{Cu}=\mathrm{Cr}<\mathrm{Pb}<\mathrm{Fe}<\mathrm{Zn}$ and $\mathrm{Cu}=\mathrm{Cr}<\mathrm{Pb}<\mathrm{Fe}<\mathrm{Zn}$ at upstream, downstream and control sites, respectively (Figure 12). The order of accumulation of heavy metals in muscle of C. watsoni, was remained as $\mathrm{Mn}=\mathrm{Pb}<\mathrm{Cu}=\mathrm{Cr}<\mathrm{Zn}<\mathrm{Fe}, \quad \mathrm{Mn}=\mathrm{Pb}=\mathrm{Cr}<\mathrm{Cu}<\mathrm{Zn}<\mathrm{Fe}$ and $\mathrm{Cu}=\mathrm{Cr}<\mathrm{Fe}<\mathrm{Z}$ at upstream, downstream and control site. $\mathrm{Pb}$ was not detected in the muscle samples of $C$. wastoni collected from the control site (Figure 13). 


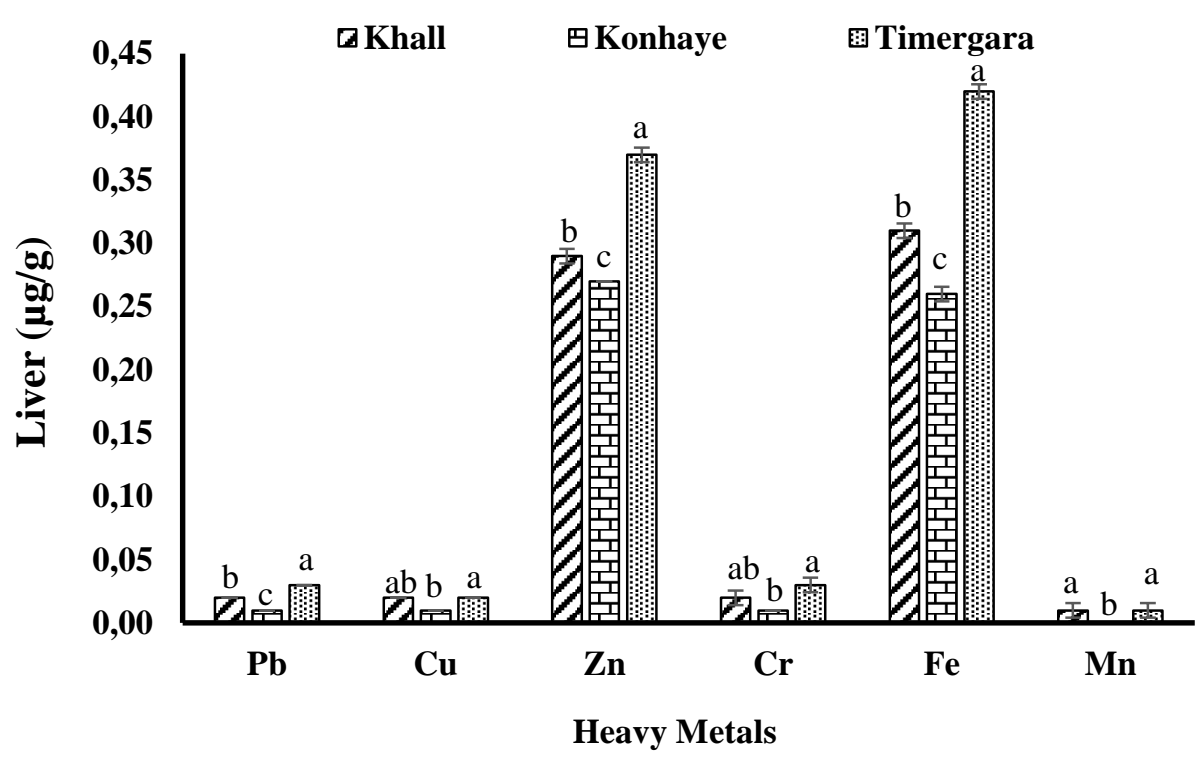

Figure 10: Concentration $(\mu \mathrm{g} / \mathrm{g})$ of heavy metals in C. watsoni liver

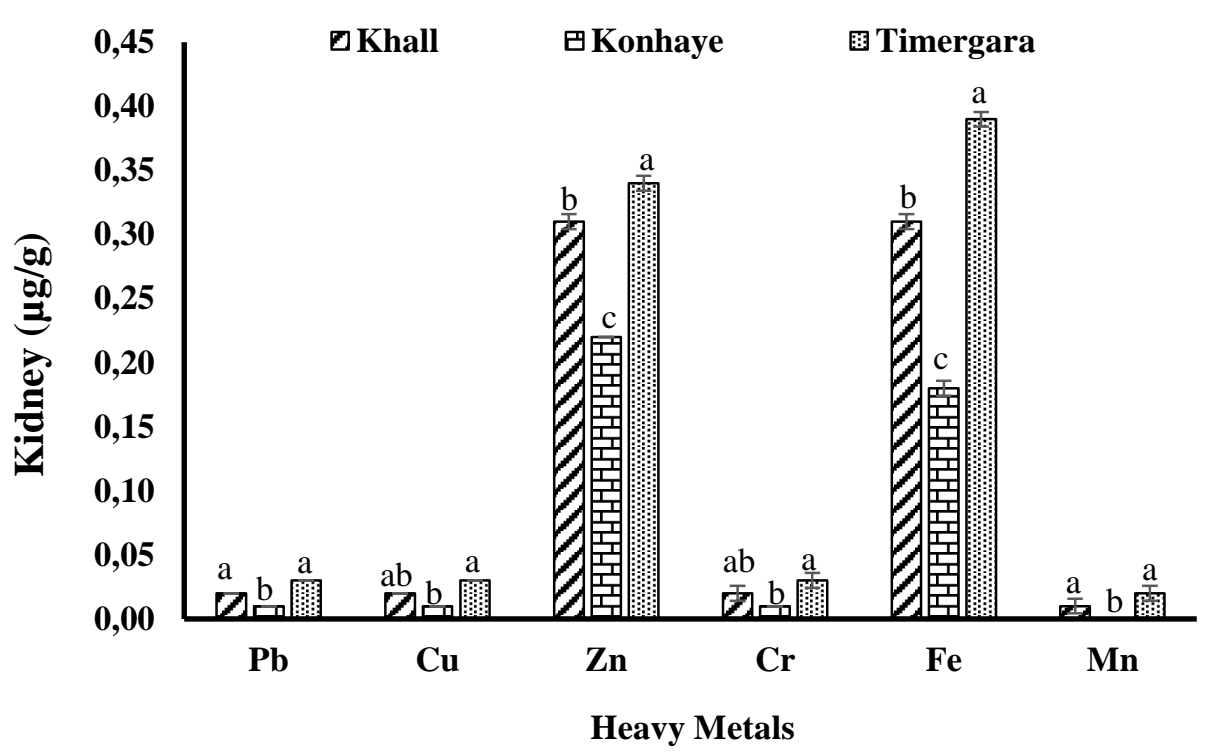

Figure 11: Concentration $(\mu \mathrm{g} / \mathrm{g})$ of heavy metals in C. watsoni kidney 


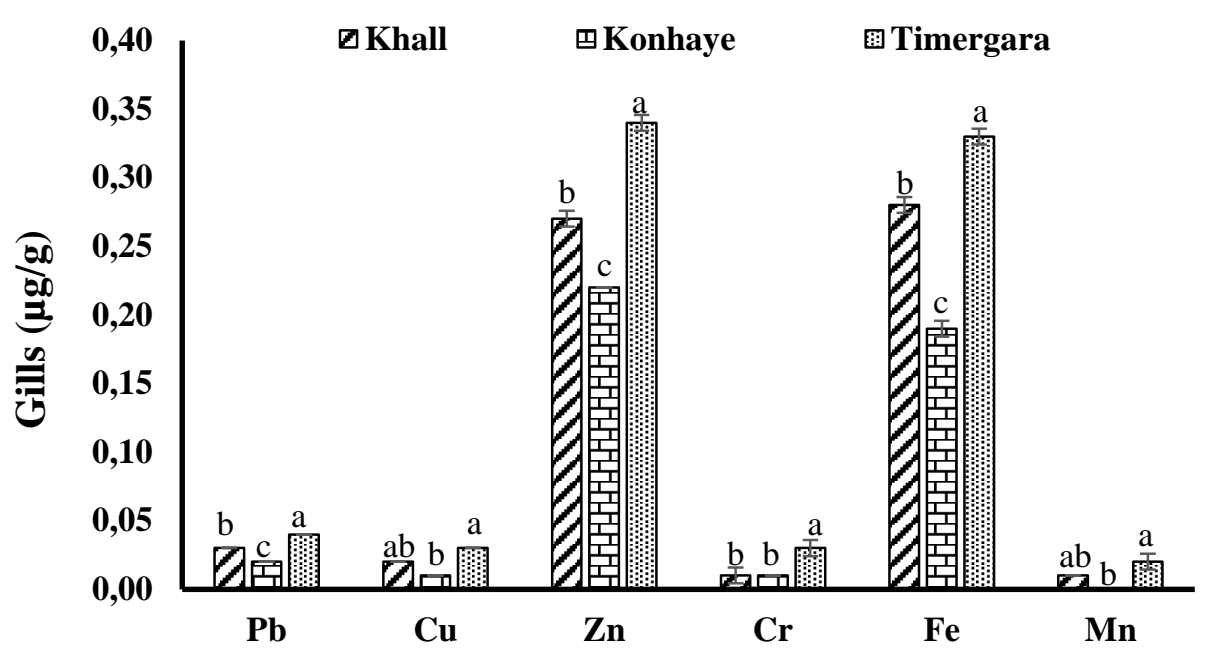

Heavy Metals

Figure 12: Concentration ( $\mu \mathrm{g} / \mathrm{g})$ of heavy metals in C. watsoni gills

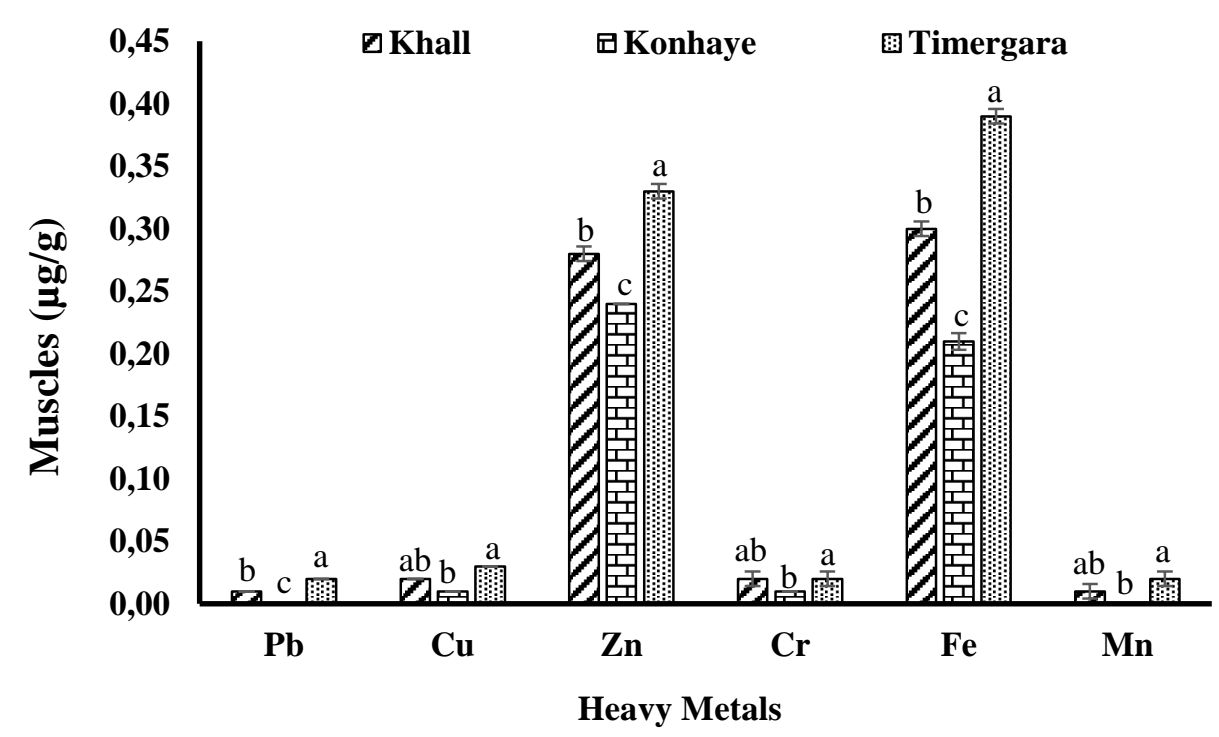

Figure 13: Concentration ( $\mu \mathrm{g} / \mathrm{g})$ of heavy metals in C. watsoni muscle

\section{DISCUSSION}

The fish species selected for the study was due to their higher consumption rate and consumer preference in the study area. The heavy metals were selected due to their availability in the study area and their potential hazards to both humans and animals, terrestrial as well as aquatic. The studied heavy metals detected in the tissues of the selected fish species were within the suggested permissible limits [23-25]. The higher concentration of $\mathrm{Zn}$ in specimens collected from both upstream and downstream might be due to the presence of rocks and minerals across the district, while increased concentration of $\mathrm{Fe}$ was observed in specimens collected at downstream might be due to direct disposal of sewages. A previous study also showed higher level of heavy metals accumulation in the tissues of Racoma labiata, Crossocheilus diplocheilus and Schizothorax esocinus, at Timergara as compared to upstream areas [1]. The concentrations of $\mathrm{Mn}, \mathrm{Pb}, \mathrm{Cu}, \mathrm{Cr}$ and $\mathrm{Zn}$ were 
higher in fishes procured from upstream compared to the reference site which might be attributed to the increased direct discharge of city wastes, effluents, agricultural runoffs and domiciliary chemicals to the river. It might also be due to the enhanced input of wastes and effluents from the heavily populated riverine areas including Rabat, Munjai, Odigram, Haji Abad, Mian Banda and Balambat situated on the banks of the river Panjkora. Among these sites the last two are more important, as these are being used as dumping site since very long for the discharge of wastes from vegetable, crockery and general markets of Timergara, the major city of the district. The concentration of heavy metals in the present study is much lower than those conducted in other parts of the Khyber Pakhtunkhwa province [16-18]. It might be due to the higher anthropogenic activities resulting in dumping and input of heavy industrial effluents and pollutants, domestic sewages and agricultural run offs into those rivers. Lower Dir district is not having heavy industries and sources of municipal effluents. Therefore, the concentrations of heavy metals were ranging under permissible limits, thus apparently optimum for human consumption. The comparison of heavy metal concentrations is rather a difficultproposition for different fish species, or even for the same tissue of different fish species because of their feedings habits, analysed tissue type, species growth rates, and variation in their ambient environment regarding the level and type of the water pollution [26].

Generally, it is thought that uptake of heavy metals takes place through consuming food or from sediment and water. Those fish species that are burrowing or bottom feeders accumulate heavy metals from the sediments, however. their efficiency of metals uptake might differ regarding their metabolism, ecological needs and the gradients of contaminants in their food, ambient water and sediments and other factors including interacting agents, temperature and salinity. It is widely accepted that heavy metals accumulation in substantial higher level might be very toxic to fish specifically for young and egg stages on account of their sensitiveness to pollution [12]. Liver, gills, kidneys and gonads active tissues metabolically and are the target organs of heavy metal accumulation in higher level [27].

Among the species $C$. carpio accumulated highest concentration of heavy metals, followed by $G$. gotyla. The differences in concentration of accumulated heavy metals might be due to the variations in ecological needs, metabolism, age, size, length, swimming behaviours and habitat of the fish species $[19,28]$. The variations might also be attributed to the capacity of different fish species of inducing metal binding proteins i.e., metallothionein. These proteins are produced in higher amount in metabolic organs such as liver. The highest amount of heavy metals was detected in liver of all the three species, as compare to other tissues, which might have enhanced the production of metallothionein in higher amount to detoxify the accumulate metals in higher concentrations [8].

The present study revealed that the level of heavy metals in Garra gotyla, Cyprinus carpio and Cyprinion watsoni were within the suggested permissible limited suggested by various International organizations. The river Panjkora can bear the burden of sewage from the neighbouring areas, but continuous increase in pollution, usage of riverine areas as picnic spots, discharge of domestic wastes and agricultural runoffs might lead to the deteriorated environmental state of the river in the future. Consequently, fish consumption from the river might pose a threat, depending on industrial and agricultural growth of the district. Further studies for establishing the relationship between fish growth and level of metal accumulation in the river should be carried out occasionally, to know its effects on the current population dynamics and development of the fish species.

\section{CONCLUSION}

It has been concluded that the heavy metals were ranged within the permissible limits and there is no apparent threat in consumption of the fish from the river. At present the river can bear the burden of the sewage system but a continuous dumping of the pollutants might lead to serious problems in the future. Regular monitoring and implementing strict environmental laws are recommended for avoiding deterioration of the environmental state of the river.

\section{ACKNOWLEDGEMENTS:}

The authors would like to express their sincere appreciation to the Deanship of Scientific Research at King Saud University for its funding of this research through the Research Group Project No. Prolific Research Group No. 1436-011. 


\section{REFERENCES}

[1] Ullah S, Hasan Z, Zuberi A. 2016. Heavy metals in three commercially valuable cyprinids in the river panjkora, district lower Dir, Khyber Pakhtunkhwa, Pakistan. Toxicol and Environ Chem 2016; 98(1): 64-76.

[2] Mahboob S, Alkahem Al-Balawi H F, Al-Misned F, Al-Quraishy S, Ahmad Z. Tissue Metal Distribution and Risk Assessment for Important Fish Species from Saudi Arabia. Bull Environ Contam Toxicol 2014; 92:61-66.

[3] Dawson E, Macklin M. Speciation of heavy metals in floodplain and flood sediments: A reconnaissance survey of the aire valley, west Yorkshire, Great Britain. Environ Geochem and Health. 1998; 20(2): 67-76.

[4] Wright P, Mason C. Spatial and seasonal variation in heavy metals in the sediments and biota of two adjacent estuaries, the Orwell and the Stour, in Eastern England. Science of the Total Environ. 1999, 226(2): 139-156.

[5] Ross SM, Kaye KJ. The meaning of metal toxicity in soil-plant systems, Ontario: Wiley and Sons. 1994.

[6] Ullah S, Hassan S, Dhama K. Level of heavy metals in two highly consumed fish species at District Lower Dir, Khyber Pakhtunkhwa, Pakistan. Pak J Biol Sci, 2016; 19(3): 115-121.

[7] Sweet LI, and Zelikoff JT. Toxicology and immunotoxicology of mercury: A comparative review in fish and humans. $\mathrm{J}$ Toxicol and Environl Heal Part B: Critical Rev, 2001; 4(2): 161-205.

[8] Canli M, Atli G. The relationships between heavy metal $(\mathrm{Cd}, \mathrm{Cr}, \mathrm{Cu}, \mathrm{Fe}, \mathrm{Pb}, \mathrm{Zn})$ levels and the size of six Mediterranean fish species. Environ Pollu. 2003; 121(1): 129-136

[9] Campbell L, Dixon D, Hecky R. A review of mercury in Lake Victoria East Africa: Implications for human and ecosystem health. J Toxicol and Environ Heal Part B: Critical Reviews, 2003; 6(4): 325-356.

[10] Ashraf W. Levels of selected heavy metals in tuna fish. Arab J Sci and Eng, 2006; 31(1A): 89.

[11] Ullah S, Zorriehzahra, MJ. Ecotoxicology: A review of pesticides induced toxicity in fish. Adv Anim Vet Sci, 2015; 3(1): 40-57.

[12] Yilmaz AB. Levels of heavy metals (Fe, $\mathrm{Cu}, \mathrm{Ni}, \mathrm{Cr}$, $\mathrm{Pb}$, and $\mathrm{Zn}$ ) in tissue of Mugil cephalus and Trachurus mediterraneus from Iskenderun bay, Turkey. Environ Res, 2013; 92(3): 277-281.

[13] Yousafzai AM, Khan A, Shakoori AR. Trace metal accumulation in the liver of an endangered south Asian freshwater fish dwelling in sub-lethal pollution. Pak J Zool, 2009; 41(1): 35-41.

[14] Nawaz S, Nagra SA, Saleem Y, Priydarshi A. Determination of heavy metals in fresh water fish species of the river ravi, pakistan compared to farmed fish varieties. Environ Monit and Assess, 2010; 167(1): 461-471.
[15] Kaur R, Dua A. Scales of freshwater fish Labeo rohita as bioindicators of water pollution in tung dhab drain, Amritsar, Punjab, India. J Toxicol and Environ Heal Part A, 2015; 78(6): 388-396.

[16] Yousafzai AM, Chivers DP, Khan AR, Ahmad I, Siraj M. Comparison of heavy metals burden in two freshwater fishes Wallago attu and Labeo dyocheilus with regard to their feeding habits in natural ecosystem. Pak J Zool, 2010; 42(5): 537-544.

[17] Yousafzai AM, Siraj M, Ahmad H, Chivers DP. Bioaccumulation of heavy metals in common carp: Implications for human health. Pak J Zool, 2012; 44(2): 489-494.

[18] Ahmad H, Yousafzai AM, Siraj M, Ahmad R, Ahmad I, Nadeem MS, Ahmad W, Akbar N, Muhammad K. Pollution problem in river kabul: Accumulation estimates of heavy metals in native fish species. BioMed Res Int, 2015. 537368 doi: 10.1155/2015/537368.

[19] Al-Ghanim K, Mahboob S, Seemab S, Sultana S, Sultana, T, Al-Misned F, Ahmed Z. Monitoring of trace metals in tissues of wallago attu (lanchi) from the indus river as an indicator of environmental pollution. Saudi J Biol Sci, 2016; 23(1): 72-78.

[20] Gundogdu A, Culha ST, Kocbas F, Culha M. Heavy metal accummulation in muscles and total bodies of mullus barbatus, trachurus trachurus and engraulis encrasicolus captured from the coast of sinop, black sea. Pak J. Zool, 2016; 48(1): 25-34.

[21] Mahboob S, Kausar S, Jabeem F, Sultana S, Sultana T, Al-Ghanim KA, Hussain B, Al-Misned F, Ahmed Z. Effect of heavy metals on liver, kidney, gills and muscles of Cyprinus carpio and Wallago attu inhabited in the Indus River. Braz Archv Tech Biol, 2016; Vol.59: e16150275, January-December 2016 dx.doi.org/10.1590/1678-4324-2016150275.

[22] Ullah S, Javed MW, Rasheed SB, Jamal Q, Aziz F, Ullah S. Assessment of groundwater quality of District Dir Lower Pakistan. Int J of Bio, 2014; 4(8): 248-255.

[23] FAO. Compilation of legal limits for hazardous substances in fish and fishery products. Fao, fishery circular 464. FAO, Rome, Italy. 1983.

[24] FAO/WHO. Evaluation of certain food additives and the contaminants mercury, lead and cadmium. W. T. R. S. N. 505 (Ed.). FAO, Rome, Italy. 1989.

[25] ITS. The ministry of the agriculture of turkey: Report 5. M. o. Agriculture (Ed.). Turkey.2000.

[26] Papagiannis I, Kagalou I, Leonardos J, Petridis D, Kalfakaou V. Copper and zinc in four freshwater fish species from lake pamvotis (Greece). Environ Int. 2004; 30: 357-362.

[27] Karadede H, Unlu E. Concentrations of some heavy metals in water, sediment and fish species from the ataturk dam lake (euphrates), Turkey. Chemosphere, 2000; 41: 1371-1376.

[28] Demirak A, Yilmaz F, Tuna AL, Ozdemir N. Heavy metals in water, sediment and tissues of leuciscus 
cephalus from a stream in southwestern Turkey. Chemosphere.2006; 63(1451-1458).

Received: January 15, 2016; Accepted: May 11, 2016 